\title{
Effect of Dietary Calcium and Phosphorus Levels on Performance of Local and Exotic Pigs
}

b)

\author{
J. O. Itori, A. A. ADEGBol $\Lambda$, \\ S. A. ADlyanju and 'I'. A. OMOLl, \\ Department of Animal Science \\ Lnizersity of Ife, Ile-Ife.
}

\section{SUMMARY}

AN experiment involving 30 Local and 30 Large White pigs was conducted to study the effect of dietary calcium and phosphorus levels on rate and efficiency of gain, carcass and bone characteristics of growing-finishing pigs.

Rate and efficiency of gain and carcass quality were not significantly different among local pigs fed varying levels of calcium and phosphorus when the same calcium; phosm phorus (Ca: $P$ ) ratio was maintained at all dietary levels. In contrast, exotic pigs receiving similar diets had a significant improvement in rate of gain. Dietary calcium and phosphorus levels affected metaca rpal length, weight and also metacarpal and turbinate ash in both breeds. Growth rate and carcass quality of local pigs were however, lower than those of exotic pigs on similar diets.

\section{INTRODUGTION}

Several investigators ('Zimmerman, Speer, Hays and Carton, I063; Libal, Peo, Andrews and Vipperman 1969 and Cromwell, Hays, Scherer and Overfield 1972 ) have shown that the calcium and phosphoros requirements for optimum gain and feed efficiency may be diflerent from that required for optimum skeletal development in pigs. Brown, Krook and Pond (1966) concluded that high levels of calcium and phosphorus were necessary to provent atrophy of the turbinate bones. (iromwell et al (1972) showed that rate and efficiency of gain and ash content of the turbinate and metacarpals were not significantly improved by increased phosphorus levels. However, they showed low dietary phosphorus levels to result in slower and less efficient gains, fatter carcasses, lower ash content in the metacarpals and a marked reduction in the ash content of the turbinates. Again, since no precise information is available on the calcium and phosphorns requirement of local pigs for optimum performanec and bone development, this study was undertaken to study the effect of different dietary calcium and phosphorus levels on the live performance, carcass traits and certain bone characteristics of growing-finishing local pigs and to compare the results thus obained with those of exotic pigs receiving the same dietary treatments.

\section{MATERIALS AND METHODS}

\section{Experimental Animals}

Sixty pigs consisting of 30 Large White (exotic) and 30 local pigs were used in this stucty. The exotic and local pigs averaging

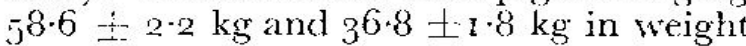
respectively were all raised on the Lniversity of Ife Pig Unit. Both the cxotic and local pigs were each randomly allotted on basis of initial weight, litter mates and sex to three cxperimental diets such that in cach group of to pigs, there were 5 barrows and 5 grilts. Pigs in each group were housed jin $7.3 \times 1.8$ meter concrete-floored pens, in an enclosed building of asbestos roofing and wooden side walls.

\section{Fxperimenlal Diets}

The diets for the three treatments were formulated to contain calcium and phosphorus levels of $0.325,0.25 ; 0.65,0.5$ and $0.975,0.75$ respectively. The calcium: phosphorus ratio was kept constant at $1 \cdot 3$ : I in all the elicts. The desired levels of calcium and phosphorus were attained by varying the amounts of dicalcium phosphate and oyster shell. Maize- groundnut cake meal diets fortified with vitamins, minerals and antibiotics and formulated 
TABLE 1

\section{Composition of Experimental Diets}

\begin{tabular}{|c|c|c|c|}
\hline \multirow{2}{*}{ Items } & \multicolumn{3}{|c|}{ Dietary treatments } \\
\hline & I & 2 & 3 \\
\hline Yellow maize & $80 \cdot 0$ & $78 \cdot 00$ & $76 \cdot 00$ \\
\hline Groundnut cake & $17.5^{6}$ & $18 \cdot 12$ & I $8 \cdot 68$ \\
\hline Dicalcium phosphate & I. 40 & $2 \cdot 80$ & $4 \cdot 20$ \\
\hline Oyster sheli & 0.04 & 0.08 & $0 \cdot 12$ \\
\hline Salt & 0.50 & 0.50 & 0.50 \\
\hline Mineral-vitamin premix 1 & 0.50 & 0.50 & 0.50 \\
\hline Total & $100 \cdot 00$ & $100 \cdot 00$ & $100 \cdot 00$ \\
\hline \multicolumn{4}{|l|}{ Calculated values } \\
\hline Protein & $15 \cdot 00$ & $15 \cdot 00$ & $15 \cdot 00$ \\
\hline Galcium & 0.325 & 0.65 & $0 \cdot 975$ \\
\hline Phosphorus & 0.25 & 0.50 & 0.75 \\
\hline Calcium: Phosphorus ratio & $1.3: 1$ & $1.3: 1$ & $1.3: 1$ \\
\hline
\end{tabular}

The vitamin-antibiotic premix supplied $440 \mathrm{mg}$ riboflavin $880 \mathrm{mg}$ calcium pantothenate, $2 \mathrm{~g}$ niacin, $2 \cdot 2 \mathrm{~g}$ choline chloride, $5 \mathrm{mg}$ folic acid, I mg vitamin $\mathrm{B}_{12}, 500 \cdot 000 \mathrm{I}$.U. vitamin $\mathrm{A}, 6,600$. I.U. vitamin $\mathrm{D}_{2}$ and I,00012 I.U. vitamin F per $50 \mathrm{~kg}$ of diet. It also supplied $24 \mathrm{ppm}$ copper, 2 ppm iodine, 34 ppm raanganese, $50 \mathrm{ppm}$ zinc and 100 ppm iron.

to contain $14 \%$ protein were used. The composition of the diets is presented in Table I. Each of the three dietary calcium and phosphorus levels was fed to one of the three groups of local and exotic pigs. Fach pen was equipped with a self feeder and a concrete water trough.

\section{Data Collection}

Pigs in each pen had access to feed and water ad libitum. Records of body weight changes and feed consumption were taken and summarised every two weeks. Local and exotic pigs were individually removed from the experiment as soon as they reached their market weights of 63.4 t I. $6 \mathrm{~kg}$ and $88.7 \pm 2 \cdot 2 \mathrm{~kg}$ respectively, after which they were slaughtered and standard carcass measurements were obtained.

One front leg from each pig was obtained following slaughter and the 2nd and 5 th metacarpal bones were excised for determining the effect of dietary calcium and phosphorus levels on their ash content. Weight and length of the $3^{\text {rd }}$ and $4^{\text {th }}$ metacarpals were also measured. The snout of each pig was also removed and the turbinates including the cartilage were then excised for ash detcrmination. The metacarpal and turbinate bone samples were ground through a Wiley mill and dried in a vacuum oven (29 inches of mercury) for 24, hours. Fat was removed from the samples by consecutive 24 hour extractions with ethyl alcohol and anhydrous ether and the resulting samples were ashed for about i 8 hours at $550^{\circ} \mathrm{C}$.

All data were analysed by the analysis of variance and treatment means compared using Duncan's multiple range test procedure as outlined by Steel and Torrie (I960).

\section{RESULTS AND DISGUSSION}

A summary of the gain, feed to gain, carcass and bone characteristics data is presented in table 2. Dietary calcium and phosphorus levels had significant effects on the rate of gain of exotic pigs. Exotic pigs on the three diets had daily weight gains of $0.3 \mathrm{r}, 0.49$ and $0.64 \mathrm{~kg}$ for diets $\mathrm{I}, 2$ and 
3 respectively, and the differences between them were significant $(\mathrm{P}<\cdot 05)$. In contrast, local pigs receiving the same diets had non-significantly $(\mathrm{P}=.05)$ different daily weight gains of $0.38,0.41$ and 0.39 $\mathrm{kg}$, respectively. Local pigs on diet I outgained their exotic counterpart on the same diet $(0.38 \mathrm{~kg}$ vs $0.3 \mathrm{I} \mathrm{kg})$, though not significantly. Exotic pigs on diet 2 outgained non-significantly the local pigs on the same diet $(0.49$ to $0.4 \mathrm{I} \mathrm{kg})$. At calcium to phosphorus levels of $0.975: 0.75 \%$ respectively, exotic pigs significantly $(\mathrm{P}<05)$ outgained local pigs $(0 \cdot 64 \mathrm{~kg}$ vs $0.39 \mathrm{~kg})$.

The National Research Council (NRC', I968) recommended level of $0.50: 0.4 \%$ calcium to phosphorus respectively, with an allowance of about $20 \%$ up, is the level used in most of our growing-finishing pig rations at the University of Ife, Swine Unit. Our observations showed that at a calcium and phosphorus level of 0.975 and $0.75 \%$ respectively, rate of gain of the exotic pigs was still on the increase. This would scem to suggest that there might have been some under-estimation of the requirement of growing-finishing exotic pigs for calcium and phosphorus under Nigeria conditions. Again, results as obtained in this study would seem to suggest that while the exotic pig was more sensitive to level of calcium and phosphorus, the local pig was more sensitive to $\mathrm{Ca}: \mathrm{P}$ ratio rather than dietary levels, for their optimum growth. Feed/gain in both exotic and local pigs were also affected by dietary calcium and phosphorus levels. Feed/gain within breeds were not significantly different at the various dietary calcium and phosphorus levels testcd, though feed/gain values tended to improve as dietary calcium and phosphorus levels was increased. Exotic pigs receiving $0.65,0.5$ and 0.975 $0.75 \%$ calcium to phosphorus, respectively, had feed/gain values significantly $(\mathrm{P}<0.5)$ higher than those of local pigs on all the dietary calcium and phosphorus levels. Feed efficiency values within brecds as obtained in this study are in agreement with those of Libal, Peo, Andrews and

TABLE 2

Effects of Dietary Calcium and Phosphorus Levels on Growth, Carcass and Bone Characteristics of Pigs

\begin{tabular}{|c|c|c|c|c|c|c|}
\hline $\begin{array}{l}\text { Calcium level, } \\
\text { Phosphorus levei, } \\
\text { Diet Number }\end{array}$ & $\begin{array}{c}0.325 \\
0 \cdot 25 \\
1\end{array}$ & $\begin{array}{c}\text { Exotic } \\
\text { Treatment } \\
0 \cdot 65 \\
0 \cdot 50 \\
2\end{array}$ & $\begin{array}{c}0.975 \\
0.75 \\
3\end{array}$ & $\begin{array}{c}0.325 \\
0.25 \\
I\end{array}$ & $\begin{array}{c}\text { Local } \\
\text { Treatment } \\
0.65 \\
0.50 \\
2\end{array}$ & $\begin{array}{c}0.975 \\
0-75 \\
3\end{array}$ \\
\hline $\begin{array}{l}\text { Growth Data } \\
\text { Av. daily gain, kg. } \\
\text { Feed/pig, kg } \\
\text { Feed/Crain }\end{array}$ & $\begin{array}{l}o \cdot 3 \mathrm{I}^{\mathrm{c}} \\
\mathrm{1} \cdot 09 \\
3 \cdot 5^{\mathrm{ab}}\end{array}$ & $\begin{array}{c}0.49^{b} \\
1 \cdot 63 \\
3 \cdot 3^{2 a}\end{array}$ & $\begin{array}{l}0 \cdot 64^{a} \\
2 \cdot 09 \\
3 \cdot 28 a\end{array}$ & $\begin{array}{l}0.3^{8 b c} \\
1 \cdot 5^{6} \\
4 \cdot I^{c}\end{array}$ & $\begin{array}{l}0 \cdot 4^{1 b c} \\
x-56 \\
3 \cdot 8 b c\end{array}$ & $\begin{array}{c}0+39 \text { bc } \\
1 \cdot 48 \\
3 \cdot 8 b c\end{array}$ \\
\hline $\begin{array}{l}\text { Carcass Data } \\
\text { Yield, \% } \\
\text { Carcass length, cm } \\
\text { Loin eye area, cm } 2 \\
\text { Backfat thickness, cm } \\
\text { a Ham and Loin }\end{array}$ & $\begin{array}{l}68 \cdot 1 \\
77 \cdot 5 \\
27 \cdot 6 \\
3 \cdot 5^{a b} \\
3^{8} \cdot 3\end{array}$ & $\begin{array}{c}69 \cdot 4 \\
77 \cdot 2 \\
28 \cdot 4 \\
3 \cdot 3^{2} \\
37 \cdot 7\end{array}$ & $\begin{array}{l}69 \cdot 2 \\
78 \cdot 2 \\
29 \cdot 2 \\
3 \cdot 2 a \\
38 \cdot 6\end{array}$ & $\begin{array}{l}6 I \cdot 3 \\
67 \cdot 5 \\
2 I \cdot 5 \\
4^{-2} \mathrm{c} \\
3^{6 \cdot 4}\end{array}$ & $\begin{array}{l}65 \cdot \mathrm{I} \\
68 \cdot 7 \\
23 \cdot 2 \\
3 \cdot 8 \mathrm{bc} \\
37 \cdot 2\end{array}$ & $\begin{array}{l}62 \cdot 2 \\
69 \cdot 8 \\
23 \cdot 1 \\
3 \cdot 8 \mathrm{bc} \\
37 \cdot 0\end{array}$ \\
\hline $\begin{array}{l}\text { Bone Data } \\
\text { Metacarpal ash, } 0^{2} \\
\text { Turbinate ash, }{ }^{2} \\
\text { Metacarpals } 3 \text { rd } \& 4^{\text {th }} \\
\text { Length, min } \\
\text { Weight, g. }\end{array}$ & $\begin{array}{l}5^{6 \cdot 2} \\
3^{6 \cdot 8}\end{array}$ & $\begin{array}{l}57 \cdot 4 \\
37 \cdot 7\end{array}$ & $\begin{array}{l}57^{\prime} \cdot 2 \\
3^{8 \cdot 4}\end{array}$ & $\begin{array}{l}50 \cdot 2 \\
33 \cdot 6\end{array}$ & $\begin{array}{l}52 \cdot 2 \\
34 \cdot 2\end{array}$ & $\begin{array}{l}51 \cdot 7 \\
34 \cdot 6\end{array}$ \\
\hline
\end{tabular}

2 Expressed on a moisture free, fat free basis

abc Means within rows with different superscripts are significantly different $(P<0.5$. 
Vipperman, (1969) who reported no significant differences in feed conversion in pigs fed various calcium and phosphorus levels.

Carcass yield and \% ham and Ioin were not significantly influenced by dielary calcium and phosphorus levels in both local and exotic pigs. Carcass length and longissimus dorsi muscle of exotic pigs werc appreciably higher than those of local pigs. A discrepancy could arise in comparing absolute values of these two parameters since the animals being compared were of varying sizes $(88.7 \mathrm{~kg}$ vs $63.4 \mathrm{~kg}$, for exotic and local pigs, respectively) at slaughter. The two parameters were hence not subjected to statistical analysis, since the slaughter weights were not subjected to constant body weights by covariance analysis. Exotic pigs had carcasses significantly $(\mathrm{P}<0.05)$ leaner at the two higher dietary calcium and phosphorus levels than local pigs on all the other treatments. Dietary increases of calcium and phosphorus tended to decrease back fat thickness in both local and exotic pigs.

Weight of the metacarpal bone (third and fourth) was greater as dictary calcium and phosphorus level of ration was increased in the exotic pigs and at the two lower dietary levels in the Iocal pigs. Metacarpal bone length was found to be longer in both local and exotic pigs up to a dietary level of 0.65 and $0.5 \%$ calcium and phosphorus, respectively, after which it decreased in both breeds. Metacarpal bone length and weight were lower in local pigs than the exotic pigs probably because of their smaller sizes. Metacarpal ash in both local and exotic pigs increased up to 0.65 and $0.5 \%$ calcium and phosphorus, respectively, whercas turbinate ash increased in both breeds with increases in dietary calcium and phosphorus levels. Cromwell et al (1972) reported that the ash content of the turbinates was not significantly correlated with the ash content of the metacarpals, thus suggesting differences in their rates of calcification. This might explain the differences in ash content relative to dietary levels of calcium and phosphorus fed in this study.

\section{REFERENCES}

Brown, W. R., Krook, I, and Pond, W. G. (1966.) Atrophic rhinitis in swine. Etiology, pathogenesis and prophylaxis. Comel Vel. Suppl. I, vol. 56 .

Crommeli, G. L., Hays, V. W., Scherer, C. W. and OvikFIELD, J.R. (1972.) Elrect of dietary calcium and phosphorus on performance and carcass, metacarpal and turbinate characteristics of swinc. J. Anim. Sci. 34, 746-751.

I.IBAY, G. W., PEO, JR. F. R., ANDREYYs R. P. and VIPPERMAN JR P. I. (ig69.) Levels of calcium and phospliorus for growing-finishing swine 7. Anim. Sci, $28,331-336$.

N. R. C. (1968.) Nutrient Requirements of Swine. Nutrient Requirements of Domestic Animals: 6th Edition. 5 Publication 1599. National Academy of Sciences, Washington, D. C.

S'Tk,L, R. G. and Torrie J. H. (I 960.) Principles and Procedures of Statistics. NoGraw-Hill Book Co., New York.

ZMMMerMaN, D. R., Spher, V. C., HAYs, V. M. and Cartox D. V. (I963; Effect of calcium and phosphorus on baby pig performance. J. Anim. Sci. 22, $658-664$. 


\title{
The efficacy of four anthelmintics in adult cattle under field conditions
}

\author{
$b y$ \\ T. W. Schillhorn van Veen \\ Faculty of Veterinary Medicine \\ Ahmadu Bello University
}

\begin{abstract}
SUMMARY
FOUR anthelmintics bithionol-sulphoxide 35-40 $\mathrm{mg} / \mathrm{kg}$. (BS) bithionol-sulphoxide combined with thiabendazole at $100 \mathrm{mg} / \mathrm{kg}$ (BS -TB-100) and at $80 \mathrm{mog} / \mathrm{kg}$ (BS +TB-80), hexachlorophene 10-15 $\mathrm{mg} / \mathrm{kg},(\mathbf{H X})$ and rafoxanide $6-8 \mathrm{mg} / \mathrm{kg}$ ( $\mathrm{RF}$ ) were used in adult cattle undcr Nigerian field conditions. Two treatment schemes were used: I one treatment a month (March) before the beginning of the rains (and the period that Fasciola infections were obtained), 2. two treatments, one a month before and one a month after the beginning of the rains.

The weight gains, egg counts, and number of animals found infected were recorded from March till August.

The total weight gain over the five months period was $37,24,5,23,24.5,15.5,17$ and $14 \mathrm{~kg}$ for the cattle treated with BS + -TB-roo, BS : TB-8o, BS (once), RF (twice), RF (once), HX (twice) and controls respectively.

The number of Fasciola infected animals decreased by the following percentages 2 weeks after treatment: 93 " for BS, $75 \%$, for $\mathrm{RF}$ and $2 \mathrm{~B}^{\prime}$ for $\mathrm{HX}$; the controls showed $a$ definite increase.

None of the treatments showed a significant reduction in the number of trichostrongyle infected animals and in egg counts, except the BS TB-roo group.
\end{abstract}

\section{INTRODUGTION}

In Nigerian cattle the helminths of the general Haemonchus, Desophagostomum, Bunostomum and Fasciola are considered of major economic importance in causing poor growth, disease or death (Lee, Armour \& Ross, r960; Sewell, r966). Haemonchosis is mainly observed during the wet season whereas oesophagostomiasis is more common during the dry season. Chronic and acute fascioliasis are mainly observed during the end of the dry scason and at the beginning of the rains. Helminth infections due to Ostertagia,
Nematodinus and lungworms which are of importance in other parts of the world are however absent (Lee et al., 1960; Schillhorn van Veen, I976).

This restricted number of clinically important helminth species is of interest since it offers opportunities for anthelmintics with a narrower efficacy spectrum than those currently manufactured and used in areas with temperate climate, including Europe, America and Australia. These opportunities are not solely of scientific but also of economic importance.

Among such anthelmintics are those with a combined efficacy against Haemochus and Fasciola such as rafoxanide and those with a combined effect against Oesophagostomum and Fasciola, for instance bithionol sulphoxide.

This paper describes a trial with such anthelmintics under Nigerian freld conditions during the end of the dry and beginning of the wet scason of 1974 .

\section{MATERIALS AND METHODS}

The trial was carried out during the period March/August on the Ahmadu Bello University farm where a mixed cattle and sheep herd was grazing at day time around the farm grounds. The animals were kraaled at night during which period they received about $\mathrm{Ikg}$ mais-silage each and frce access to saltlicks.

The 93 adult fermale cattle with naturally acquired helminth infections were divided into seven groups and treated as follows: 
(i) (I I animals) treated with bithionol sulphoxide a. (40 $\mathrm{mg} / \mathrm{kg}$ ) on the 15th of March and with a combination $\mathrm{b}$. of bithionol sulphoxide (40 $\mathrm{mg} / \mathrm{kg}$ ) and thiabendazole (I $00 \mathrm{mg} / \mathrm{kg}$ ) c. on the $x_{5}$ th of May.

(ii) (I I animals) treated as I but the dosage of Thiabendazole was 80 $\mathrm{mg} / \mathrm{kg}$. d.

(iii) (Io animals) treated with bithionol sulphoxide $(40 \mathrm{mg} / \mathrm{kg})$ on the $15^{\mathrm{th}}$ of March.

(iv) (15 animals) treated with rafoxanide e. $(7.5 \mathrm{mg} / \mathrm{kg})$ on the $15^{\text {th }}$ of March and on the $1^{\text {th }}$ of May.

(v) (15 animals) treated with rafoxanide $(7.5 \mathrm{mg} / \mathrm{kg})$ on the $15^{\text {th }}$ of March.

(vi) (I6 animals) treated with hexachlorophene f. $(15 \mathrm{mg} / \mathrm{kg})$ on the I $5^{\text {th }}$ of March and on the 15 of May.

(vii) (15 animals) constituted the control group which reccived no treatment.

Table I gives a schematic presentation of the treatment scheme. The animals were assigned to groups in such a way that the age, weights and level of helminth infection (as measured by cgg counts) were comparable.

During the trial however some of the cattlc calved and although they were equally distributed over the groups, these animals were eliminated from the trial as far as their weights were concerned, reason why there was a difference in the average weight per group at the beginning of the trial on the $15^{\text {th }}$ of March.

Rectal faecal samples were taken and animal weights recorded on cvery first Friday of the month from April till August.

Faecal examination was performed according to the modified McMaster egg counting technique (Whitlock, 1948) for nematode eggs and according to the modified formal ether method (Sapero and Lawless, I953) for the trematode egg.

\section{RESULTS}

The treatment with all anthelmintics on the $15^{\text {th }}$ of March (table 2) caused a reduction in number of animals in which Fasciola eggs could be detected, and in the

TABLE 1

Treatment Scheme Used in University Farm Cattle

\begin{tabular}{|c|c|c|}
\hline Group & Treatment on $15^{\text {th }}$ March & Treatment on I $5^{\text {lh }} \mathrm{May}$ \\
\hline I & & $\begin{array}{l}\text { Bithionol-sulphoxide and Thiabendazo } \\
\text { 100 } \mathrm{mg} / \mathrm{kg}\end{array}$ \\
\hline II & Bithionol-sulphoxide & $\begin{array}{l}\text { Bithionol-sulphoxide and Thiaben- } \\
\text { dazole } 80 \mathrm{mg} / \mathrm{kg}\end{array}$ \\
\hline III & & Nil \\
\hline iv & Rafoxanide & Rafoxanide \\
\hline VI & Hexachlorophene & Hexachlorophene \\
\hline VII & Nil & $\mathrm{NiI}$ \\
\hline
\end{tabular}

a. Disto-5 (Cogla Cy. -paris)

b. Wormy-ro (Cogla Cy.-paris)

c. Thiabendazole (Merck, Sharp \& Dohme - Rahway, U.S.)

d. Wormy r-8 (Cogla Cy. -paris)

e. Ranide (Merck, Sharp \& Dohme - Rahway, U.S.)

f. Facsol (Cooper, McDougal \& Robertson, Berkhamsted U.K.) 
TABLE 2

Number of Animals out of Total with Eggs Detected at Day of Treatment (I5th of March) and 2 and 6 Weeks Afterwards

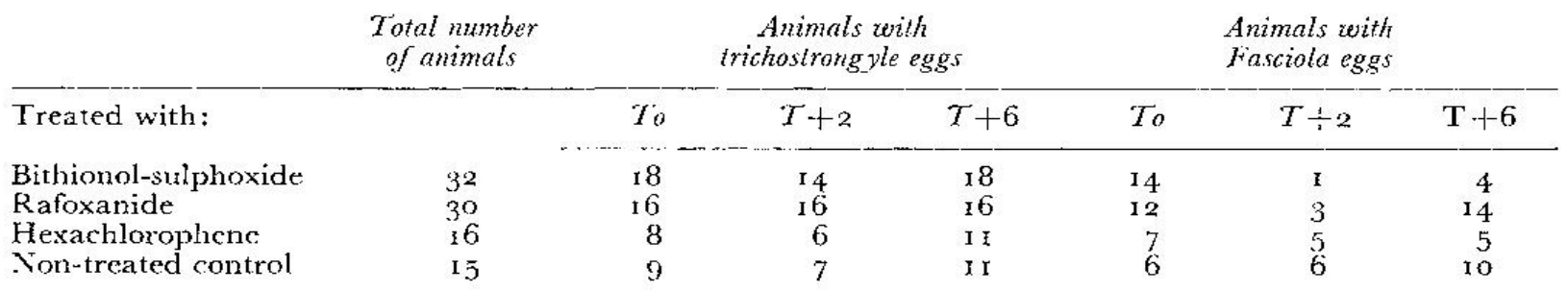

TABLE 3

Number of Animals out of Total with Eggs Detected 2 Weeks before, 2 Weeks after and 6 Weeks after Treatment (r5th of May)

\begin{tabular}{|c|c|c|c|c|c|c|c|}
\hline \multirow[t]{2}{*}{ Treatment groups: } & \multirow[t]{2}{*}{$\begin{array}{l}\text { Total number } \\
\text { of animals }\end{array}$} & \multicolumn{3}{|c|}{$\begin{array}{l}\text { Animals with } \\
\text { trichostrongyle eggs }\end{array}$} & \multicolumn{3}{|c|}{$\begin{array}{l}\text { Animals with } \\
\text { Fasciola eggs }\end{array}$} \\
\hline & & $7+2$ & $T+2$ & $7+6$ & $T \cdot[-2$ & $T+2$ & $T-6$ \\
\hline I & II & 7 & I & 5 & 2 & 0 & I \\
\hline II & II & 7 & 2 & 5 & I & 0 & 2 \\
\hline III & 10 & 4 & 4 & 5 & $\mathrm{I}$ & 4 & 5 \\
\hline IV & I 5 & 10 & 8 & 7 & 8 & 6 & 9 \\
\hline V & I 5 & 6 & 9 & 12 & 6 & 6 & ris \\
\hline VI Control & I 6 & I I & 9 & Io & 3 & 4 & 5 \\
\hline VII Control & 15 & I I & 10 & IO & Io & 6 & 10 \\
\hline
\end{tabular}

number of Fasciola eggs per animal. None of the drugs reduced the number of animals with detectable trichstrongylid infections.

The treatment on the $15^{\text {th }}$ of May (table 3) confirmed this result. 'The effect of the thiabendazole was noticed in that the number of animals with a detectable gastro-intestinal trichostrongylid infection as well as their average trichostrongylid egg counts, declined considerably. The difference in mean egg counts was however not statistically significant.

Paramphistome-eggs were rarely found during March and April but were demonstrated in five control animals, two rafoxanide and three hexachlorophene treated animals in May-June. In July - August howcver 20 animals were found infected, one group III, 3 of IV, 6 of V and 5 each in group VI and in the control group.

The weight change of the animals during the last months of the dry season were, low or negative (figure 2).

The weight gains (or losses) in the animals treated with bithionol sulphoxide
( $\varangle \mathrm{Ikg})$ and rafoxanide $(-2 \mathrm{~kg})$ were statistically lower $(\mathrm{P}<0.05)$ than those treated with hexachlorophene $\left(\begin{array}{lll}-6 & \mathrm{~kg}\end{array}\right)$ and the non-treated control $(-6 \mathrm{~kg})$. After May however the weights increased and the weight gain over the period MayAugust of the groups one to seven was 36 , $22.5,22.5,24.5,20,23$ and $20 \mathrm{~kg}$ respectively. The total weight gain over the period March-August was respectively 37 , $24.5,23,24.5,17$ and $14 \mathrm{~kg}$. Only the weight gain in group I was statistically different from the controls $(\mathrm{P}<0.05)$.

\section{DISGUSSION}

The efficacy of the drugs used in this field trial was not very convincing in that none of the utilised drugs completely eliminated the helminth-infection within the group. With regards to fascioliasis however it should be pointed out the treatments were carried out during the period that freshly acquired flukes developed; a few cases of (fatal) acutc fascioliasis were recorded in shcep grazing in the same 
herd during April. Boray (1971) in a review on the chemotherapy of $F$. hepatica mentioned that hexachlorophene at 15 $\mathrm{mg} / \mathrm{kg}$ had little or no effect on juvenile flukes, rafoxanide only at a dosage of 7 - Io $\mathrm{mg} / \mathrm{kg}$. Also bithionol sulphoxide has little effect on llukes of less than 8 wecks.

Especially the effect of rafoxanide was bclow cxpectation. The reduction in number of infected animals was transient (table I) and could well be due to a temporary reduction egg production. This is in contradiction with various other reports on the efficacy of rafoxanide against $F$. gigantica (Bouchet, Daynes \& Birgi, I97 I ; Snyders, Louw, 1971) and it may be useful to repeat the trial with a higher number of animals before drawing definite conchusions on the efficacy against $F$. gigantica. Snyders, Horak and Louw (1971) found a $100 \%$ reduction in the number of cattle infected with adult $F$. gigantica but noticed that the drug at a dosage rate of $5-7.5$ $\mathrm{mg} / \mathrm{kg}$ was less efficient in reducing the juvenile fluke population.

Also Presidente and Knapp (I972) still found $F$. hepalica eggs in artificially infected calves after treatment with rafoxanide, especially at the dosage of $7.5 \mathrm{mg} / \mathrm{kg}$ or less.

It scems interesting that neither bithionol sulphoxide with a clained efficacy against Oesophagostomum spp. nor rafoxanide with a claimed efficacy against Haemonchus spp. caused any reduction in trichostrongylid egg counts. Only when combined with thiabendazole was the reduction detectable (figure r). "The trichostrongylid egg counts were generally low, the highest recorded was $25^{\circ}$ e.p.g. and only hall of these (adult.) animals had a detectable number of eggs in the faeces. It is possible however that the detected eggs were mainly Cooperia cggs, which were not affected by the drugs used. Lee el al. (1960) in the adjacent Shika Research Station found that Cooperia eggs were especially prevalent in faecal sarriples of cattle during the period May-July. Since the rains started late in 1974 , it is inlikely that IIaemonchus sp. recently developed in the pasture could contribute to the egg counts during April and May. I'he first period with a rainfall of more than $5 \mathrm{~cm}$. per week, a requirement for optimal development of Haemonchus, was the second wock of June.

Better weight gains were recorded in the animals treated twicc, which indicated that the elimination of the residual adult fluke population as well as the recently developed flukes was of detectable benefit to the host. The difference in weight loss 6 weeks after the first treatment shows that the reduction of the adult fluke population only as done by hexachlerophene seems less important than the reduction of adult and juvenile flukes as affected by rafoxanide and bithionol. It is possible however that this picture was biased since the latter two drugs do also affect a part of the nemotode population and show some activity against paramplistomes. The effect of rafoxanide against these stomach flukes was rather poor which is in agrccment with the results of Bouchet et al. (1971).

This difference in weight gains was less obvious however during the beginning of the rainy season when fodder condition improved. This is in accordance with firtings of Graber (I97 I) who postulated that the detcriorating eflect of Liverfluke infections is especially evident in animals on a low nutritional level.

The long term effects of the treatment were less obvious; the differences in weight gain during the last two months of the trial were minor.

Concluding it should be stated that the two treatments were justified in that the weight gains in these groups (I, II, IV) were at least $23 \mathrm{~kg}$ higher than the nontreated controls. The costs of drug and treatment were below one naira per animal whereas the profit, based on a price No.6o per $\mathrm{kg}$ live weight, was over 12 naira per animal.

The single treatment in March showed little effect and was probably ill-timed at a period that juvenile flukes were just obtained and not affected by the drugs used.

\section{REFERENCES}

Boray. J. (A. 197 I. Fortschritte in der Bekamplung der Fasciolose. Schwciz. Arch. Tierheilk, 113, $361-386$. 
Poucher, A., DAYNes. P, and BIrgr. E. (1971.) Etude de 1 action anthelmintigue d'un derive halogene de la salicylanilide vis-a.-vis de Fasciola giganlica. Rex d'Elev. Med. Vet. Pays tropic. 24, $542 \quad 549$.

Grabir, M. (rg7i.) Role du facteur alinentaire dans la distomatose bovine at oveni a Fasciolia gigantica. Bull. rpizoot. Dis. Afr. 19, 4560.

L.Ee, R. P., Armovr: J and Ross J. G. (1960) The scasonal varialions of strongyle infestations in Nigerian zebu caltle. 'The Brit. Vet. J. r16, I 13 -

Presidente, P. J. A. and K.vaps, S. F. (1972.) Anthetmintic effect of rafoxanide against immature fasciola hepatica in catves. Am. J. Vet. Res. 33, 1603-1610.

SApEro, J. T., and I.Awress, 1). I. (T95.3.) The M.J.J. stain-preservation technic for the identification of intestinal protoma. Am. J. lrop. Ned. Hyg. 2, 6r3-6rg.
Scimllhord yay Vhex T. W. (1976.) Some notes on anthelmintic treatment in Nigerian ruminants. J. Med. Pharm. Marketing 4, 273275.

Sirwki.L. M. M. H. (xg66.) The pathogenesis of Fascioliasis. Vet. Rec. $\mathbf{7}^{\mathbf{8}}, 9^{8-105}$.

SNyDers, A.J., Louw, J. P. and SERRAxo, F. M. H. (1971.) Trials with rafoxanide. I. Fasciola gigantica in catlle in Angola J. S. Afr. Vet. Nied. Ass. 42, 249-25x.

Sryders, A.J., Horak, I. G. and Louw. J. P. (I971.) Trials with rafoxanide. 2. Efficacy against rasciola gigantica in cattle. J. S. Aft. Vet. Med. Ass. 42, 253-257.

Whitrock, J. H. (1948.) Some modifications of the McMaster egg counting technique and apparatus. J. Counc. Scient. Industr. Res. Austr. 21, $177-130$. 